\title{
MANAGING MALAYSIAN BORDER: THE CHALLENGES AND PROSPECTS IN MAINTAINING SECURITY
}

\author{
Noor Azmi Mohd Zainol ${ }^{1}$ \\ Department of Nationhood, Leadership and Civilization, \\ National Defence University of Malaysia, Kuala Lumpur, Malaysia. \\ (Email: noorazmi@upnm.edu.my/azmi7172@gmail.com) \\ Anwar Zamani Jusop ${ }^{2}$ \\ $17^{\text {th }}$ Royal Malay Regiment, Terendak Camp, Malacca, Malaysia. \\ (Email: anwarzamani711@gmail.com) \\ Ahmad Azan Ridzuan ${ }^{3}$ \\ Department of Defence Human Resource Management, \\ National Defence University of Malaysia, Kuala Lumpur, Malaysia. \\ (Email: azan6142@yahoo.com) \\ Sofian Kamaruddin 4 \\ Department of Strategic Studies, \\ National Defence University of Malaysia, Kuala Lumpur, Malaysia. \\ (Email: sofian@upnm.edu.my)
}

Received date: $21-09-2019$

Revised date: $30-10-2019$

Accepted date: 23-11-2019

Published date: 15-12-2019

To cite this document: Zainol, N. A. M., Jusop, A. Z., Ridzuan, A. A., \& Kamaruddin, S. (2019). Managing Malaysian Border: The Challenges and Prospects in Maintaining Security. International Journal of Politics, Public Policy and Social Work, 1(3), 01-13.

DOI: $10.35631 /$ ijppsw.13001

Abstract: This paper aims to examine the challenges encountered by Malaysia enforcement border agencies to protect the sovereignty of Malaysia and its prospects of integration among various agencies at the border. With a wide boundary, the Malaysian security is porous to various threats which not only mean a traditional military threat but also include multiple threats. Current threats have been broadening to include transnational criminals such as illegal immigrants, smuggling people or prohibited goods or even non-traditional threats such as terrorism. In order to control such threats, there are several government agencies and legal enforcement which are responsible to protect Malaysian sovereignty such as The Royal Malaysian Police, Royal Malaysian Customs Department, Malaysian Department of Immigration, and Malaysian Border Control Agency and Malaysian Armed Forces as well. These agencies are responsible to manage the Malaysian border at various legal checkpoints such as air, sea and land checkpoints. The Malaysian Armed Forces, on the other hand, has been responsible to manage illegal route along the Malaysian border especially in the jungle. In order to manage a broad scope and complexities of the border, some scholars develop a concept of Coordinated Border Management (CBM) or Integrated Border Management or Collaborative Border Management, or Comprehensive Border Management in order to 
integrate all different border agencies. There is an urgent need for border agencies to coordinate their actions in order to improve the effectiveness and efficiency of border procedures. All the challenges will discuss further in this article.

Keywords: Border, Transnational Criminals, Non-Traditional Threats

\section{Introduction}

Malaysia is a strategically located in the centre of Southeast Asia with Peninsular Malaysia as the most southern point of three continents, Europe, Russia and Asia. Peninsular mark the separation of two big oceans, the Indian Ocean and South China Sea. Sabah and Sarawak on the other hand surrounded by maritime area but also connected with the Philippine and Indonesia. Geographically, Malaysian border comprise of two territories; West Malaysia (Peninsular Malaysia) and East Malaysia (Sabah and Sarawak). Both territories are separated by the South China Sea. Peninsular Malaysia encompasses 131,585 sq kilometers (km) while East Malaysia encompasses 9,210,080 sq km lies across $650 \mathrm{~km}$ of the South China Sea in the Island of Borneo. As a single country, Malaysia is a neighbor to Thailand, Indonesia, Brunei Singapore, and the Philippines (Ruhanas, 2009). Malaysian international borders are as follows:

\section{The Malaysia and Thailand Border}

Malaysia and Thailand shared a land and maritime border. The Land border lies for about 646.5 kilometers $(\mathrm{km})$ from Perlis to Kelantan.

\section{Malaysia and Indonesia Border}

Malaysia also shares a border with Indonesia in Sumatera and Kalimantan. Boundaries with Sumatera specifically maritime border stretches for $805 \mathrm{~km}$ along the Straits of Malacca while East Malaysia (Sabah and Sarawak) share a border with Kalimantan by land for 2,019.5 km.

\section{Malaysia and Brunei Border}

Malaysia also shares a border with Brunei which encompasses of 481.3 KM of land border.

\section{Malaysia, the Philippine and Singapore}

Malaysia, the Philippines and Singapore are divided by maritime border namely the Straits of Sulu and Tebrau.

With a wide boundary, the Malaysian security is porous to various threats which are not limited to traditional military threats but also other threats. However, the threats have been broaden to transnational criminals such as illegal immigrants, human trafficking and smuggling of prohibited goods or even of non-traditional threats such as terrorism. There are several agencies are responsible to manage the Malaysian border at 138 authorized checkpoints such as air, sea and land checkpoints. These agencies are the Royal Malaysian Police or Polis Diraja Malaysia (PDRM), Royal Malaysian Customs Department or Jabatan Kastam Diraja Malaysia (KDRM), Malaysian Department of Immigration or Jabatan Imigresen Malaysia (Immigration) and Malaysian Border Control Agency or Agensi Kawalan Sempadan Malaysia (AKSEM) Malaysia Maritime Enforcement Agency or Agensi Penguatkuasaan Maritim Malaysia (APMM) and not to forget the Malaysian Armed Forces as well. These agencies are responsible to manage the Malaysian border at various authorized checkpoints such as air, sea and land checkpoints. 
The border of the country has to be protected and secured in order to guarantee the peace, stability and sovereignty. States border are a national asset which assists the country's economic assets, strategic values and political stability. National borders also allow trading, social and cultural activities and apply rules of law within its society. All countries must protect their survivability and sovereignty by eradicating crime within their boundaries (Morrison, 2014). There are two types of national borders:

\section{Legal Crossing Points}

Legal crossing points along the border line of Malaysia can be divided as land crossing points, maritime crossing point (ports) or airspace crossing points (airports). The crossing points are as follows:

\section{Land Crossing Points}

The land crossing points in Malaysia are divided into two types which is 'official' and 'unofficial'. The 'official' land crossing of Peninsular are for example as Padang Besar and Wang Kelian in Perlis, Bukit Kayu Hitam and Durian Burung in Kedah, Pengkalan Hulu in Perak, Bukit Bunga, Rantau Panjang and Pengkalan Kubor in Kelantan. As for Sarawak and Kalimantan, there is only one official land border which is Tebedu. However, there is numerous 'unofficial' land borders crossing between Sarawak and Kalimantan such as Serikin (near Kuching), Bario (Kelabit Highland) and Sapulut (Sabah);

\section{Airports}

Airports in Malaysia are also considered as legal cross points (entry and exit points). The airports are for example Alor Setar Airport, Langkawi Airport, Kuala Lumpur International Airport, Melaka Airport, Kuching International Airport and Kota Kinabalu International Airport; and

\section{Sea-Ports}

Sea-ports in Malaysia are for example Penang Port in Penang, Port Klang in Selangor and Tanjung Pagar port in Johor. However, there were several ports which is regularly used by Indonesia (particularly Sumatera) for entry/exit point such as Melaka and Muar as entry/exit point from Bengkalis and Dumai; Lumut for Belawan; and Batu Pahat for Selat Panjang. For Sabah, the entry/exit point is Tawau for Nunukan and Tarakan (East Kalimantan).

\section{Illegal Crossing Points}

Besides the legal crossing points along the border, there are several established illegal crossing points. The established illegal crossing points by the transnational organize crime have been used for human trafficking, illegal immigrant and smuggling activities along Malaysia Thailand border. The illegal crossing points between Malaysia and Thailand exist in developed areas and along the jungle fringe at the border. The illegal cross points along the Malaysian border therefore shows that Malaysian border were porous and vulnerable to threats. Inefficient dealings with vulnerabilities will exacerbate the threats. The vulnerabilities of Malaysian border had become the most important and questionable issues of border enforcement agencies efficiency. The border control at every Malaysia's entry point must be strengthen. The border agencies such as Malaysian Department of Immigration, Royal Malaysian Customs Department, Royal Malaysian Police, Malaysia Border Control Agency, Malaysia Maritime Enforcement Agency must play their role in order to protect Malaysia's stability from any threats. The Malaysian Armed Forces also has their own roles and task to neutralize the threats at their designated area of responsibility. 
There are numbers of illegal cross points along the Malaysian border indicate the border were porous and vulnerable to threats. Inefficient dealings with vulnerabilities will exacerbate the threats. The vulnerabilities of Malaysian border had become the most important and questionable issues of border enforcement agencies efficiency. The border enforcement agencies at every entry point must be strengthen and play their role in order to protect Malaysia's stability from any threats.

\section{The Challenges}

\section{Porous Border}

Malaysian borders are porous to threats due to the geographical factor of Malaysia which is located in the center of South East Asia. The threats encountered by Malaysia are worsening due to the 'spill-over' effect and 'push and pull' factors of neighboring countries. The issues of Thailand and the Philippines government at the southern part of their regions with Muslim communities have a long and unresolved conflict until now. It can be proven through the serious kidnapping activities by Abu Sayyaf group of Southern Mindanao in the area of Sabah since year 2000. The activities of kidnapping and demanding for ransom have threatened Malaysian security and affected Malaysian tourism. The repeated kidnapping incidents in Sabah lately has converged a negative impact on Malaysia tourism industry (Norizawati, 2014).

Malaysian and Indonesian border is more vulnerable, and it exposes more threats. Malaysia and Indonesia share a huge land and maritime border. With a population of 230 million people with similar language, religion and tradition, illegal immigrants of Indonesia undisputedly is a threat to Malaysian's security. Malaysia as a newly industrialized country with a huge development, economic and political stability has 'pull' a mass migration of other ASEAN nations especially from Indonesian, Myanmar, Thailand and the Philippines to Malaysia. This is unfortunately, will cause another issue of threat namely 'trans-national crime' (Ruhanas, 2009). The border of Malaysia is porous in two types of entry/exit point which is through legal cross point or illegal cross point. It can be scrutinized as follows:

\section{Legal Cross Point}

The legal cross point along the border can be considered porous due to lack of integrity and technology at the border enforcement agency. The integrity of the border enforcement agencies is the ultimate important which leads to the problem of border security. Apart from question of integrity by the enforcement agency at the border, the technical issue and lack of advanced technology equipment also contribute to this problem.

\section{Illegal Cross Point}

Most of the Malaysian land border are intentionally underdeveloped and covered with jungle fringe. Criminals make full use of this vulnerability for their advantage. Furthermore, maritime border along Malaysian border also considered as the most vulnerable to piracy because it covers a vast area of Malaysia. As example of undeveloped area which is along MalaysiaThailand border is Sg Golok, Kelantan. It covers $29.9 \mathrm{~km}$ from Rantau Panjang to Pangkalan Kubor, Kelantan. Besides the legal crossing points in Pangkalan Kubor and Rantau Panjang border, the communities along the border remain preferred illegal routes along the border to conduct their day to day activities (Fauzi, 2013).

\section{Virtual Border}

International borders are so porous that they are no longer played their important role as a barrier of ideas, a movement of people and goods or to an extent of no longer important to the 
power of the state (Laitinen, 2004). Virtual border is the impact of globalization of the world. Globalization will increase the activities of transnational crimes, money laundering, cybercrime, smuggling, piracy, human trafficking and migration. Some scholars relate the globalization with systemic boundaries. Navniit (2010) in his book indicates that the current boundaries can be characterized as systemic boundaries because it is less territorial or ideological rather than before. As a result, failure to address domestic priorities will affect the political agenda of the government and jeopardize economic development of the nation and create uneasiness to community which in the end will create threats internally. National security has come to mean the security of a whole socio political entity.

Aniszewki (2009) suggests that in the $21^{\text {st }}$ century, the concept of physical border has emerged from the traditional concept although it is still intact. The definition of national border should be observed beyond the delineation of the national frontier and should be changed. The risk having threats can be anywhere not only at the frontier of national border. The protection of the border should be well managed before any travellers or goods enter the national border. Therefore the border control must be maintained 'well forward' in another country and 'well backward' into our country itself.

Basically, border security's aim is to facilitate a lawful traveller and trader; and to prevent any person who has a 'communication disease' to enter a country (Rosenblum, 2013). The current procedures of checking and inspection by various enforcement agencies at the border area are ineffective. As for Malaysia situation, Mr. Ahmad Rasdi Hussain (2016), a Customs officer at Bukit Kayu Hitam, Kedah mentioned during his briefing that the border security enforcement at Bukit Kayu Hitam ICQS is inefficient because it is not well equipped. The numerous checking by various enforcement agencies are redundant at times. The checking procedures of goods and individuals are time consuming and slow down the flows of travel and trade when time is very crucial in certain situation. Therefore, it needs a new advanced technology like a scanner that can scan thoroughly a container or body and less time consumption needed.

\section{Ethnic Communities along the Border}

Historically, before the delineation of the modern border, every nation or ethnic shared a common identity and culture. They were recognized through their ethnicity or religion. The establishment of the borders has changed the significance of ethnicity. The ethnicity has been separated from their community by the modern border and recognized through their citizenship of the state and nationality. Though divided by the border, the continuity of the culture and economy are still maintained because of the relationship. Therefore, the non-physical element along the border has to be considered in discussing the border management security. The border area where the same community lived before the establishment of a country's boundaries will pose a certain issue such as movement across the national border and the requirement of certain immigration document. The biggest challenge is that the community believes that they have a right to move beyond the borders despite being separated by the borders. This is the situation at Sarawak-Kalimantan border communities at Serikin (Suhana, 2014).

The same case also can be observed among the border community in North and East region of Peninsular Malaysia especially along Kedah, Perak and Kelantan border. Along the southern border of Thailand, Malay-muslim community shares the same language, customs and religion with the Northern part of Malaysia. Historically, the region of Southern Thailand was part of the ancient Malay Kingdom, Langkasuka. The region claims independence and pay a tribute to Siamese Empire of Ayutthaya as its vassal kingdom. Finally, it is under the Siamese controlled state under the Anglo Siamese Treaty of 1909 with British (Rupprecht, 2014). Not to forget the 
Javanese Community on the West Coast of Peninsular Malaysia with Indonesia and Bajau Laut community with the Philippines (Ramli, 2015).

\section{Transfusion of Threat}

Criminal network transfusion pervades in its own ring and is more complex in the globalization world. It may be elaborated in a situation where a trafficking organization (either human trafficking or contraband trafficking) may transfuse their activities with an unauthorized migrant or terrorism. They may integrate and cooperate with an organized crime and may use same techniques or the same routes.

Most unauthorized migrants enter into any country through a legal cross point either by land, seaport or airport and overstay in that country. Smugglers can successfully snake in goods through cargoes and check points due to lack of new scanning technology. It is worth to states that, it is impossible for border security enforcement at legal cross points to contain criminal activities at the border (Rosenblum, 2013).

\section{Lack of Authority to the Armed Forces}

Besides the challenges faced by the Legal Cross points at the Malaysia national border, there are several illegal cross points at the Malaysia - Thailand and Malaysia - Indonesia border. These borders have been maintained and protected by the Malaysian Army. According to Acting Chief of Staff of $30^{\text {th }}$ Brigade and Chief of Staff of $6^{\text {th }}$ Infantry Brigade (2016) during a briefing at $5^{\text {th }}$ Border Regiment mentioned that the challenge faced by the Malaysian Armed Forces during the operation at Malaysia - Thailand border is lack of legal authority. The operation Malaysian Armed Forces had been deployed to the border area of Malaysia Thailand in the northern region especially Kedah and Perak without any authority of law with regard to power of arrest, search and seizure. The Armed Forces had a sufficient legal power before the abolishment of the Internal Security Act 1960 by the government in order to conduct their operations. Section 64, Section 65 and Section 73 of the Internal Security Act 1960 had provided a power to the Armed Forces with regard to arrest, search and seizure.

\section{Failure to Assess Threat}

According to Navniit (2010), the concept of security is previously focused on the military dimension, especially the perceptions of threats by an elite, doctrinal response, security resources and capabilities to encounter the external threats. The assessment of threat and security was more focused on two clusters of variables which is security environment and the availability of hardware. However, he stressed out that the proper assessment of overall security need to be paid more to software security management which involve political context and policy capacity through the definition of national values, perceived of threat and vulnerabilities, the allocation of resources and the implementation of policies. The concept of security acquires an operational meaning when threat is identified. There is an implicit and explicit determination of threat security against recession, illegal search and seizure and inflation or erosion. Therefore, failure by the government or enforcement agencies to assess threats accurately is a threat by itself.

National security can no longer be preserved by defending the border. National interest of a country must be protected beyond the delineation of border. There are three categories of National interest, which are: 


\section{Vital Interest}

Vital interest is broad and very important for the country's survival. It includes physical security of a country (its territory), the safety of its citizens and economic well-being of the people. This must be protected at all cost. The threat could be neutralized through the use of military force.

\section{Important Interest}

The threat to a country's security may not be direct. The volatile neighboring countries would affect the instability and threaten the country indirectly.

\section{Humanitarian Interest}

This category of interest will not affect the country's boundaries directly, but the threat could affect national values such as natural/ man-made disaster or violation of human rights. The threat could be neutralized through diplomacy or cooperation with Non-Governmental Organization (NGO) or other government.

\section{The Prospect}

Malaysia have experienced in dealing with internal threat during the First and Second Emergency by neutralizing communist ideology in Malaya fully utilize all the government agency and assets including the Armed Forces and other government agencies. This strategy adopted by General Sir Harold Briggs known as the 'Briggs Plan'. The Armed Forces conducted a search and destroy operation while other government agencies assisted the multiracial communities to improve their qualities of life through various government programs (Federation of Malaya, 1951). Therefore, in order to win the battle with multi facet and multi-dimensional threat, all national components must perform their part. The combination of government policy and its agency, the security forces plan and its personnel, the population strive and its efforts will formulate a quality of strategy against one common enemy.

\section{Malaysia's Plan}

Malaysia had produced $7^{\text {th }}$ Strategy Paper which is $10^{\text {th }}$ Malaysia Plan (2011-2015) and $11^{\text {th }}$ Malaysia Plan (2016 - 2020). This strategic plan was aim to create a safer living space and secure environment for Malaysian. The Malaysia's plan is as follows:

\section{Collaboration of Border Security Agencies}

According to the plan, the government of Malaysia will enhance the capabilities and effectiveness of all border enforcement agencies through collaboration. The collaboration will include sharing of information and data among law enforcement agencies. The government was determined to provide border security either entry or exit point with current monitoring system and border detection and surveillance equipment.

\section{Increase Community Participation}

The government also decided to increase volunteerism and participation of Malaysian communities to enhance public security. This action will serve a better relationship among the Malaysian. For that purpose, government will promote RELA or Jabatan Sukarelawan Malaysia and APM or Angkatan Pertahanan Awam Malaysia (Malaysian Civil Defense Force). 


\section{Intensified Crime Prevention}

The crime prevention by the security force will be intensified with redeployment of special task force. The public confidence will be reinstalled through cordial engagement by the security force and the public.

By engaging the holistic strategy of winning 'hearts and minds of the people', it is expected that the crime rate will be reduce and the confidence will be intensified among the Malaysian citizens.

\section{Action by Ministry of Home Affairs}

The Ministry of Home Affairs had come out with their strategic plan. The Strategic Plan of 2015-2020 has been formulated to establish and improve many essential areas, but three main cores will be highlighted as it relevant with the border security such as:

\section{Strict Immigration Law}

The Ministry of Home Affairs will embrace a strict immigration law in order to control the influx of illegal immigrant and human trafficking activities in Malaysia. The Immigration department will further heighten cooperation with other government agencies through 'open door' policy. The less formality policy will help reduce time consuming and boost efficiency of the department.

\section{Enhance Border Security}

The Ministry of Home Affairs will enhance border security of Malaysia through the coordinating and cooperation of enforcement agencies by sharing of intelligence information.

\section{Neutralized Transnational Crime}

Transnational crime will be the main focus of Ministry of Home Affairs to be neutralized. Failure to address this issue may affect the whole Malaysia to be the base for the transnational organized crime.

\section{National Defence Policy}

Historically, Malaysian Armed Forces (MAF) had successfully protecting Malaysian citizen from internal or external threat. The (MAF) had played a vital part during the emergency which led the communist to surrender. Accordingly, the Malaysia's National Defence Policy has been revisited in order to develop and modernize MAF by taken into consideration of nonconventional threat that may jeopardize and affect Malaysia's sovereignty, independence and integrity. The primary objective of MAF Defence Policy is to protect and defend Malaysia's national interest through 'Total Defence strategy' and 'Self-Reliance'. Malaysia's national interest is divided into three areas which is:

\section{Core Areas}

The core areas encompass Peninsular Malaysia, Sabah and Sarawak including its territorial waters and airspace.

\section{The Offshore Economic Areas}

The offshore economic areas are Malaysia's Economic Zone of Exclusive (EEZ) and its continental shelf. 


\section{Strategic Waterways and Airspace}

The strategic waterways and airspace are (1) Maritime and airspace lines of communication connecting Peninsular Malaysia and Sabah and Sarawak; (2) Straits of Malacca and its approaches; and (3) Straits of Singapore and its approaches.

The establishment of the Border Brigade on 29 January 2008 marks a new chapter of border security in Malaysia. This brigade specially known as $30^{\text {th }}$ Brigade is meant to protect Malaysian land border from external threat. The primary role of Malaysian Army in Land Border Operations has been specified in the Manual of Land Border Operation as "to defend Malaysia sovereignty from any threat." (MP 3.2.2 TD, 2012). Malaysian government has boost up the border security by establishing another Border Brigade which is $31^{\text {st }}$ Brigade located at Bintulu, Sarawak in order to tighten Sarawak border security. Therefore, it is clear evidence that national defence plan and the $11^{\text {th }}$ Malaysia Plan are accomplishing each other to achieve stability and protect Malaysia sovereignty from internal or external threat. Their primary tasks are:

(1) conduct operations as forward elements to avoid any military external threat; and

(2) deny any form of encroachment at border area/line.

Whereas their secondary task are:

(1) maintaining/enforcing law and order at national land borders;

(2) apprehend the activities of illegal immigrants;

(3) denying illegal crossing activities along national land borders;

(4) denying smuggling activities along national land borders;

(5) to conduct hearts and minds activities; and

(6) to coordinate with other agencies on operational matters.

\section{Coordinated Border Town Development}

The prospect of securing national security can also be procured through the development of national border by Trans-border cooperation. It is obvious that the populations along the border are interconnected with each other for a long time. The relationship among border community should be entertained. Therefore, a brilliant idea of the then Deputy Prime Minister of Malaysia Dato' Musa Hitam is the vibrant to control the illegal transaction and cross boundaries between Malaysia and Indonesia (Kalimantan). Trans-border Cooperation between Malaysia and Indonesia has been mooted during the tenure of Dato' Musa Hitam on $14^{\text {th }}$ November 1983 when he was a chairman of General Border Committee of the $12^{\text {th }}$ Session held in Kuala Lumpur. It got a positive response by General LB Moerdani as Commander of Indonesia Armed Forces (Chairman of the GBC Indonesia).

Based on the decision of the Chairman of the Joint GBC Malindo and the Chairman of GBC Indonesia, Socio-Economic Cooperation-Malindo or Sosek-Malindo of West Kalimantan Indonesia was established by a Decree of the Governor of West Kalimantan No. 408 of 1985 on 21 Dec 1985 (Ariffin, 2012). The vision of Sosek-Malindo is, "achieving harmony and sustainable socio-economic development for the mutual benefit, especially in the border between two countries." The cooperation between two countries is still continued their research which focusing on border crossing, traffic control procedures, customs, immigrations and quarantine. The research also been conducted to integrate postal inspection in Entikong Tebedu for traditional border crossing which will be set up as cross-border checkpoint in the near future. The discussion for Badau - Lubuk Antu Integrated Postal Inspection as cross border check points also is in mind (Suhana et al., 2013). 


\section{Establishment of Malaysia Border Control Agency (AKSEM)}

The establishment of Malaysia Border Control Agency (AKSEM) was among the bright prospect of border security management by the Malaysian government. AKSEM consist of various enforcement of government agencies such as Royal Malaysian Customs, Malaysian Department of Immigration, Royal Malaysian Police, Malaysia Civil Defense, National AntiDrug Agency, Kenaf and Tobacco State Institution was established on $2^{\text {nd }}$ November 2015. The AKSEM was the upgrading of Anti-Smuggling Unit or Unit Pencegah Penyeludupan (UPP) to Border Control Agency or Agensi Kawalan Sempadan Malaysia (AKSEM) (Utusan Malaysia, 2015).

The main aim that led to the establishment of AKSEM is to minimized crime rate of smuggling activities at Malaysia - Thailand border such as illegal immigrant, human trafficking and drug smuggling. It is also meant to be a lead agency for collaboration of various border enforcement agencies. AKSEM currently revising Standard Operating Procedure (SOP) in order to integrate various enforcement procedures under the same policies. The establishment of AKSEM is one of the government determinant to protect Malaysia sovereignty particularly along the border from any external threat either traditional or non-traditional threat.

\section{Collaboration with Interpol}

According to Interpol, people and goods are easier to cross international borders in globalized world. Criminal are exploiting the globalization for their strength. They used globalization to cross other country's border and commit crimes. After the completion of crimes, they escape to other country and at the same time they escape justice because of state boundaries. Serious crime such as trans-organize crime, human trafficking, smuggling of illegal and contraband goods are all take advantage of weak security screening at international border crossings (Interpol, 2014).

With regard to the border management, Interpol had established an "Integrated Border Management Task Force" (IBMTF) to assist the member state to enhance their border security procedures. This task force has vast experience to integrate border security efforts within neighbouring state. The function of IBMTF is to coordinate operational activities, training opportunities and offers partnership with international organizations in ensuring border security. In this regard, Interpol will share their database with enforcement agencies at sea port, airport or land border crossing of the member state via Edison TD (INTERPOL Travel and ID Document Reference Centre). Interpol also leads and coordinates border security enforcement operation to disrupt trans-border crime that using fraudulent documents to conceal their true identity (Interpol, 2014).

\section{Application of "Coordinated Border Management (CBM)"}

Coordinated Border Management or $\mathrm{CBM}$ can be define as a "national or international coordination and cooperation among agencies and authorities in the border which involved security and trade to facilitate and integrate border management systems obtaining their common objective which is a controlled and secure borders." CBM has been implemented in several countries especially European countries. The implementation of CBM can increase an effective and efficiency of the border service and reduce the redundant of policies and procedures among the different agencies (Anizewski, 2009).

CBM also can save government economies by using integrated ICT systems, integrated training, development and managing human resources. Therefore, CBM can strengthen an ability to address other strategic challenges in the country. The efficient management of borders 
will benefit travellers and traders. The CBM can mitigate the country's burden by targeting the real suspect and the high risks shipment and travellers through sharing of information and intelligent by both countries (Anizewski, 2009). The CBM approach only requires a strong political will with a full cooperation and involvement of private sector. The CBM propagate two types of Border Management which is Domestic Management and International Border management. According to Customs World Organization, Domestic Border Management is related with two stages:

\section{Intra-service Cooperation}

Intra-service cooperation is cooperation among various departments in the government either through cooperation at the administrative level or working group level at the national border.

\section{Inter-agency Cooperation}

Inter-agency cooperation is cooperation among various border agencies either at state or federal level. The cooperation can be in the sort of integrated procedures, integrated risk management system, integrated policy, training, development and etc.

\section{International Cooperation}

It is the cooperation among two neighboring countries either through bilateral agreement, MOU or any declaration. This may be operated by the concept of "one stop border post" which two countries operate and collaborate together in just one post (Anizewski, 2009). This cooperation would beneficial to boost economy, mitigate the burden of traders and traveller and reduce time consumption when dealing with the border agencies. The challenges for the international cooperation would be in term of different work cultures and organization system.

A research by Boriboonrat (2013) based on the data collected in the border check point of Aranyaprathet and Sadao, Thailand. Boriboonrat (2013) recommended a conceptual framework of "Border Crossing Management" to find an appropriate approach to manage the border. Accordingly, he suggested that Thailand should implement Collaborative Border Management System (CBM) within the customs entry point because it is best situated to develop integrated procedures for goods processing. Immigration and police would continue to process the people at point of entry. The researcher also emphasize that CBM need a political support from the highest level (Boriboonrat, 2013).

\section{Conclusion}

Despite all the efforts taken by Malaysia, it must be conceded that there is still a lot of work to do toward greater security. Indeed a number of challenges have continued to embrace Malaysian along with its efforts. Definition of border issue always focused on physical elements either natural or man-made elements such as rivers, mountain, walls, towers, fence or even barbed wires to identify the boundaries or border. A balance approach between security policy, economic policy, a clear policy on economic management and developing management resources by the border enforcement unit will make national border issue which relate to security will be effectively manage.

For developing country like Malaysia, protect a national border is a problematic issue. The country which fails to protect border will consider a failed country. To solve the problems of border, it requires the involvement and association of many sectors and department. All the government agencies must work together and share information to help diagnose the problems. With related to this, border crossing management and security needs to shy away from traditional management which emphasis on the regulations, patterns, command and control. 
The CBM offers a different structure with a strict of strict regulations towards the management of inter-agency cooperation with flexibility and adaptability.

Sir Gerald Templer, the High Commissioner of Malaya rightly stated that "...the answer lies not in pouring more troops in to the jungle, but in the hearts and minds of the people" (Hishamuddin, 2015). This quotation was rightly understood and implemented by Malaya government at that time. Thus, the quotation is still relevant in the current situations. In order to neutralized the multi facet threat faced by Malaysia, all sort of elements must be combined and working together to eliminate the threat. It is not lies on security forces, government agencies or political parties but also the Malaysian population as whole.

Therefore, securitization is important to eliminate threats. The dynamics of all security categories are determined by securitizing actors and referents object. According to Collins (2013), the securitizing actors are 'actors who securitized issues by declaring something existentially threatens' such as governments, political leaders, bureaucrats, lobbyists and pressure groups. Referent objects, on the other hands are, 'things that are seen to be existentially threatened and that have a legitimate claim to survival.' Referent objects can be the state (military security), national sovereignty or ideology (political security), national economies (economic security), collective identities (societal security) and species or habitats (environmental security).

\section{Acknowledgement}

The authors wish to thank the National Defence University of Malaysia for funding this research under the Short Term Research Grant Scheme (UPNM/2016/GPJP/3/SSK/6).

\section{References}

Ahmad Rasdi, H. Customs Officer at Bukit Kayu Hitam during a visit to ICQS (Immigration, Customs and Quarantine Security) at Bukit Kayu Hitam, Kedah for Exercise KAJIMATAN MAFSC Students Course 45/2016 to Northern area on 27 July 2016.

Aniszewki, S. (2009). A Concept Paper of Coordinated Border Management, WCO Research Paper, No. 2, 2009.

Briefing by Acting Chief of Staff of $30^{\text {th }}$ Border Brigade during a visit at 5 th Border Regiment, at Bukit Kayu Hitam, Kedah for Exercise KAJIMATAN MAFSC Students Course 45/2016 to Northern area on 27 July 2016.

Briefing by Chief of Staff of $6^{\text {th }}$ Infantry Brigade during a visit at 5th Border Regiment, at Bukit Kayu Hitam, Kedah for Exercise KAJIMATAN MAFSC Students Course 45/2016 to Northern area on 27 July 2016.

Buzan, B. (1983). People, State and Fear: The National Security Problem in International Relations, Wheatsheaf, Great Britain.

Collins, A. (2013). Contemporary Security Studies, $3^{\text {rd }}$ Eds., United Kingdom: Oxford University Press, 2013.

Fauzi, H. Norehan, A. Hussin, A. \& Selamah, M. (2013). Aktiviti Ekonomi Sempadan di Perairan Sg. Golok-Rantau Panjang: Isu dan Cabaran. Proceeding PERKEM VIII, 2013, pp. 235-245.

Federation of Malaya. (1951). Annual Report on the Federation of Malaya. Kuala Lumpur: Government Printer, 12-13.

Hishamuddin Tun Hussein, Dato' Seri, 2015, Extrimism and Militancy: A Challenge to National Security, Midas Digest 3/2015, Kuala Lumpur: MiDAS.

Laitinen, K. (2004). Reflecting the Security Border in the Post-Cold War Context. The International Journal of Peace Studies. 6(2). 
MP 3.2.2 TD, 2012, Land Border Operations, Kuala Lumpur: Malaysian Army Training Command.

Navniit, G. (2010). National Security: Emerging Dimension and Threats, Pentagon Press.

Norizawati, M.A. \& Tarmiji, M. (2014) "Issues of Safety and Security: New Challenging to Malaysia Tourism Industry," access on 30 April $2018<\mathrm{http}: / /$ www.shsconferences.org/ articles/ shsconf/ pdf/ 2014/ 09/ shsconf_4ictr2014_01083.pdf

Ramli, D., Marsitah, M.R., Wan Shawaluddin, W.H. \& Amrullah, M. (2015). Elemen fizikal dan bukan-fizikal dalam pembentukan identiti komuniti sempadan di Pantai Timur Sabah, Malaysia. Geografia: Malaysian Journal of Society and Space. 11(7), pp. 9-20.

Rosenblum, M.R. (2013). Border Security: Understanding Threat at U.S. Border. Congressional Research Service, CRS Report for Congress.

Ruhanas, H. (2009). Peningkatan Keselamatan Bersama Melalui Kerjasama Duahala Malaysia dan Negara-negara Jiran. Jebat. 36, pp. 16-40.

Rupprecht, K. (2014). Separatist Conflict in the ASEAN Region: Comparing Southern Thailand and Mindanao. Austrian Journal of South-East Asian Studies. 7(1), pp. 21-40.

Suhana, S., Junaenah, S., Noor Rahamah, A.B., Abd Hair, A., Mohd Yusof, A. \& Ong, P.L. (2014). Local Leadership and Social Cohesion at Malaysia-Indonesia Border. Global Journal of Human Science: Interdisciplinary, 14 (3), pp. 17-22.

Utusan Malaysia. (2015). UPP kini dikenali Agensi Keselamatan Sempadan. published in on 3 Nov 2015. 